Griswold, mated to a Mountain hen which we had banded last year as a juvenile in another nestbox just $1 \frac{1}{4}$ miles away. After the five eggs hatched at this second nest, we set up a blind and took many pictures, mainly of the male bluebird, since he was a most unusual looking specimen: in addition to an extremely deep blue back and blue throat, he had much chestnut down his flanks, raising the question as to whether he might be a cross between the Mountain and West. ern Bluebirds.

The "Southeast Line" under Ed Robinson's direction listed 58 bluebird nestings from 100 nestboxes, an excellent percentage. The "Southwest Line" with Stan Giles and Art Michie in charge had an equally good percentage of success and in addition one of the nests in this area held the first Cowbird's egg ever found on our nestlines. We are sorry to report that the Rev. H. Dykman, who started our "Northwest Line" several years ago, has moved with his family to B.C., and his extensive nestline, running from south of Kenton north to Hamiota, west to Miniota, and south to Hargrave, has now been added to our main complex.

The banding of bluebirds again occupied much of our time this summer. Beginning in late May we banded until early August with a total of 4162 bluebirds. Of this total, 3475 were Mountain Bluebirds, 662 Easterns, and 25 hybrids. West of Brandon the malady which struck the firstbrood young in 1970 , as reported in Blue Jay, Dec., 1970, recurred this summer in the same areas. An esti. mated 100 nests were affected and 450 young bluebirds died, including the first two broods of hybrids. Specimens sent to a laboratory in Winnipeg for tests failed to reveal any concrete causes, but specimens of a small fly which we invariably found sucking blood from the young in the affected nests were identified as the common black-fly, and we now believe these, rather than some poison spray, to be the cause of the epidemic. In addition to these newly-established enemies of the bluebirds, we found a flying squir- rel in one nestbox, and paper-making wasps which had taken over in another. These insects completely shrouded the box in their grey paper, then built their tiers of combs inside. In areas of evergreens porcupines are becoming a nuisance by climbing fenceposts and chewing up those nestboxes which are partly built of plywoods; we have been told it is the glue they are after. Deer mice, House Sparrows, House Wrens, and several types of ants continue to invade our nests, with both mice and sparrows on the increase. Starling have not become the menace that we feared, possibly because we are now installing smaller holes over the normal nesthole in areas where this species threatens. Our total nestings for 1972 are:

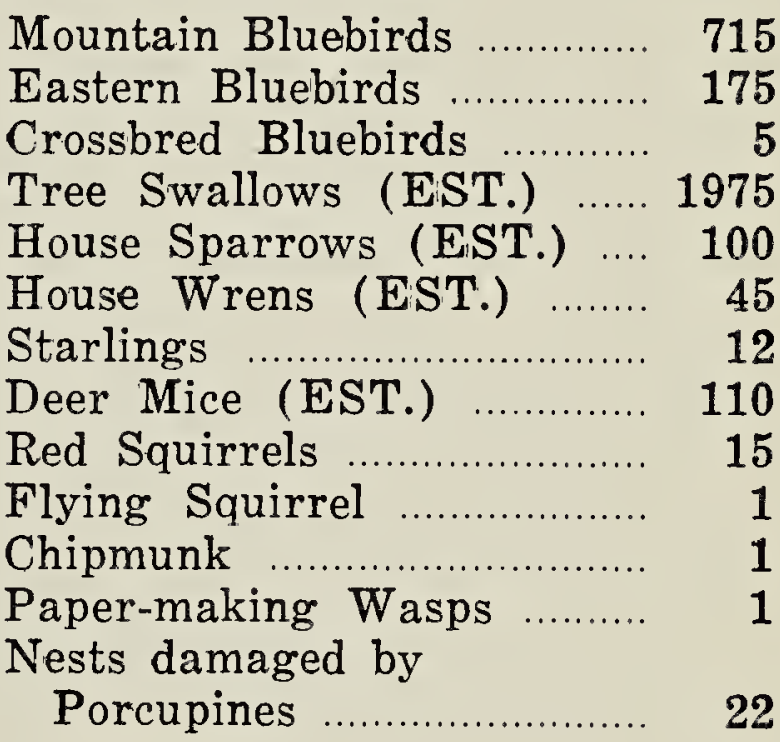

\section{ANNUAL REPORT ON THE INDIAN HEAD BLUEBIRD TRAIL}

An additional 200 nest boxes were set out last spring, bringing the 10 year total to over 1,400 houses. Two new trails were established; one runs southeast of Regina along highway No. 16 to highway No. 35, then north on No. 35 to the Trans-Canada Highway. The other trail runs northwest of Regina on highway No. 11 to Lumsden, then north on highway No. 20 along the east side of Last Mountain Lake past Silton.

There were about 250 nests of Mountain Bluebirds in the houses this year, an increase of some 50 nests over last year. About 1,000 young (Continued on page 253) 


\section{Letters and Notes}

\section{DRAINAGE OF WETLANDS}

Last winter the provincial government advised the SNHS that a Wetlands Project Advisory Committee was being formed which would consist of four representatives of agricultural interests and four from wildlife organizations and invited it to name a representative. The Committee considers proposals about which there are conflicts of interest, and advises the Wetlands Project Committee which consists of the deputy ministers of Natural Resources, Environment and Agriculture. In turn, the latter group make recommendations to the government.

The wetlands projects so far to come before the Committee are schemes to completely or partially drain sloughs, marshes and lakes for agricultural purposes. Seventy-five per cent of the work is paid for out of ARDA (federal) funds, and 25 per cent by the local ratepayers. Over 100 projects have been mentioned, but only those involving conflict of interest come to the Committee. So far 14 projects have been considered in five meetings, two of which involved public hearings. One drainage project was recommended not to go ahead, one to receive further study, and the other 12 to proceed (six of these on somewhat reduced scale).

Three schemes involve the draining of only one body of water. Others, however, are quite large: one has 157 miles of drainage and lateral ditches; another drains an area encompassing over 100 potholes.

To farmers able to place more land into production and to operate more efficiently there can be a financial gain from the drainage of wetlands. That other farmers have reservations for a variety of reasons is also evident.

A number of features about the pro. gram are of concern to me. That one federal program is paying to drain potholes while another is paying to preserve wetlands seems patently inconsistent. The information provided to the Committee about the wildlife and other natural values has been meagre. There has been no input regarding environmental factors. As there are many proposed projects (some involving several townships), questions about the total, mass effects of drainage are of considerable concern. What will be the effect on downstream flooding in the spring? What will be the effect, if any, on ground water levels? What, if any, will be the effect on micro-climates? What will the resultant countryside be like? Why are ARDA funds being used in a quite different way in Saskatchewan than in Ontario? Should there not be overall guidelines to achieve a balance? These questions were asked but no sound answers were received.

These reservations were pointed out to Mr. G. R. Bowerman, Minister of Natural Resources, in a recent meeting with him. A moratorium on further drainage projects was recommended while the broad implications are determined and policy recognizing all factors is established.-J. A. Wedgwood, Saskatoon.

\section{Annual Report on the Indian Head Bluebird Trail}

(Continued from page 227)

were raised in the successful nests. Seventy-five adult female Mountain Bluebirds were caught on nests and banded. Also 18 females that had been banded in previous years were caught again this year. Some of these females were banded three years ago in 1969 . Three of the females recaught this year were banded as young birds in the houses in earlier years. A total of 625 young Mountain Bluebirds were banded this season.

Tree Swallows occupied over 500 houses and raised well over 2,000 young. Two hundred adult female Tree Swallows were caught while incubating their eggs and banded. An additional 50 adult females were captured already wearing bands put on 
them during the three previous years. Nine of these females were banded as young birds in the houses and the remaining 41 were banded as adults.

Since I began making bird houses in 1963 , there has been a grand total of about 800 Mountain Bluebird nests producing over 3,000 young, and some 1,800 Tree Swallow nests producing over 8,000 young.-Lorne Scott, Indian Head, Saskatchewan.

\section{A REPORT ON THE BROADVIEW BLUEBIRD TRAIL}

An additional 75 nest boxes were set out last fall, increasing the number of houses on our trail to 175. This bluebird trail project was started in 1969.

Mountain Bluebirds occupied 32 of the 75 new houses, and Tree Swallows also nested in 32 of the new houses. About 370 young Mountain Bluebirds were raised from approximately 74 nests last spring. This is an increase of about 54 nests over last year. Tree Swallows occupied about 68 nest boxes, an increase of nine nests over last year. Some 367 young were fledged.

The houses are situated south of Broadview, forming a triangle with boundaries of the area extending from two miles west of Broadview, east to Percival, and 10 miles south of Broadview. - David Chaskavich and Don Weidl, Broadview, Saskatchewan.

\section{HOUSE WREN AND TREE SWALLOW}

On June 11, when checking bird house No, 27, which was being used by Tree Swallows, I was very surprised to find three House Wren eggs in the nest with five Tree Swallow eggs.

On June 22, I again checked the nest, and found the three House Wren eggs on top of the five Tree Swallow eggs.

On July 2, the nest contained one young House Wren and five young Tree Swallows.

On July 12, the young Wren was flying around, accompanied by both adult Tree Swallows. The five young Tree Swallows were still in the nest.

When the nest was vacant, I cleaned the box, and examined the contents. The lower section of the nest had been built by House Sparrows, and contained a dead adult Tree Swallow. Over this the Wrens had built their nest of twigs. The Tree Swallows then took over and added more feathers.

The House Wren and the Tree Swallow must have laid their eggs when the other was out of the nest. I did not see the adult Wrens.

I have to report that no bluebirds used the houses again this year.John L. Murray, Lyleton, Manitoba.

\section{BIRD BOXES HELPED BLUEBIRD SPREAD TOWARD THE EAST}

The Mountain Bluebird, once a western Canadian species, has been gradually extending its range eastward over the past number of years. This range expansion has no doubt been helped along by the efforts of clubs and individuals in setting out nest boxes.

The Birds Hill Park Bluebird Lane, which has put up a sizeable number of boxes in various parts of Manitoba, had two pairs of Mountain Bluebirds nesting on the east side of Birds Hill Provincial Park last summer. One pair nested at the junction of roads No. 206 and No. 212 in box No. L-16 and the other pair nested half a mile north of that in box No. L-26.

The first pair of Mountain Bluebirds were spotted on April 14 by me while I was inspecting some boxes two miles south of the junction of highway No. 44 and road No. 206. On April 21, the same pair (presumably) were seen inspecting some more boxes at the junction of roads No. 206 and No. 212 . This time they were seen by George Grzybowski as well as myself. On April 28, I found a nest belonging to this pair in box No. L-16. At that time no eggs had been laid. On May 5, one egg was present and on May 12, six had been laid. This was unchanged on May 20 when my brother Eric saw the 